\title{
Moving Toward Environmental Sustainability: ICTs, Freight Transport, and $\mathrm{CO}_{2}$ Emissions
}

\author{
Walid Chatti, Ph.D. \\ Faculty of Economics and Administration, King Abdulaziz University, 21589 Jeddah (KSA) \\ (Phone: +966564068081; E-mail: wshati@kau.edu.sa)
}

\begin{abstract}
The link between ICTs, freight transport, and $\mathrm{CO}_{2}$ emissions has not received much explicit examination by researchers, despite freight transportation being an egregious contributor to environmental degradation. This paper investigates how ICTs can affect environmental quality when interacting with freight transport activities in 43 countries over the period 2002-2014, using carbon emissions as a proxy for environmental damages. ICTs are measured in terms of internet, telephone, and mobile phone technologies. Using GMM methodology, the results show that ICTs contribute to dampening environmental degradation when interacting with freight transport activities. Specifically, a 10\% increase in the interaction between ICTs and freight transportation will decrease carbon emissions by between $1.27 \%$ and $3.02 \%$. The results further suggest that fixed and smartphone technologies are the main contributors to reducing emissions when adopted in some specific transport sectors (i.e. road, rail, and inland), while the internet is the most efficient technology when interacting with air transport activity. In addition, the interaction between ICTs and multimodality accelerates environmental quality. The policy implications of these findings are discussed.
\end{abstract}

Keywords: ICTs, Freight transport, $\mathrm{CO}_{2}$ emissions, Environment, Panel data 


\section{Introduction}

Transport systems actively contribute to the socio-economic development of countries. Freight transport essentially facilitates access to goods and materials, comprising the main distribution channels of imports and exports. However, freight activity is a major contributor to global atmospheric pollution, especially the road transport sector, and if the average global temperature increases by $2^{\circ} \mathrm{C}$, the impacts are expected to be catastrophic for environmental quality (IPCC 2014; McKinnon 2016; Santos 2017). According to the International Energy Agency (2016), transportation represents $30 \%$ of the EU's total GHG, of which road transport represented $72 \%$ in 2016. Despite relevant efforts made in other sectors of economy, pollution has increased for the transport sector, and its eventual reduction appears prohibitively expensive because the system and the global economy as a whole is highly dependent on fossil fuel consumption and traditional associated infrastructures (Santos 2017; Chatti et al. 2019). Therefore, both governments and transport companies have attempted to profit from some innovative solutions to dampen energy consumption, and thus reduce the environmental degradation associated with their activities.

Despite the key role that can be played by ICTs in reducing $\mathrm{CO}_{2}$ emissions, few studies have investigated the links between ICTs, freight activity, and environment (Wang et al. 2015; Chatti 2020; Centobelli et al. 2020a, 2020b). Few empirical papers explicitly show how ICTs reduce pollution where interacting with freight transport. The existing literature is focused in general on the identification of green practices and new technologies employed by industrial and service companies (Wang et al. 2015), but fails to identify the most efficient new technologies that can significantly decrease the environmental damages (Centobelli et al. 2020a, 2020b; Chatti 2020). In addition, most studies have paid more attention to road freight transport, neglecting the responsibility of other transportation modes in increasing pollution (e.g. air, rail, and sea).

This study aims to enrich the existent literature by exploring how new technologies interact with freight transport to improve environmental quality with regard to carbon emissions reductions. The main contributions are presented as following. First, it aims to identify the most efficient technology that can dampen the negative impacts of freight transport activities (i.e. road, rail, inland, and air). Second, it sheds light on the importance of combining both new technologies and multimodality (i.e. road-rail) as an ambitious solution for reducing pollution. Third, it attempts to 
explicitly propose an empirical analysis that quantify the real effect of using new technologies in freight transportation on environment. Finally, it provides some practical policies in order to positively affect environmental quality for both developing and developed countries.

\section{Literature review}

Several papers have examined the question of environmental sustainability in relation to $\mathrm{CO}_{2}$ emissions reductions. Some of them attempted to examine the links relating ICTs to environmental damages (Añón Higón et al. 2017; Park et al. 2018; Asongu et al. 2019), supply chain management and logistics (Cucchiella and Koh 2012; Nilsson and Sternberg 2017; Oláh et al. 2017; Molero et al. 2019; Centobelli et al. 2020a, 2020b), and freight transport (Giannopoulos 2004; Ozcan and Apergis 2018; Tob-Ogua et al. 2018; Centobelli et al. 2020a, 2020b; Chatti 2020).

To understand the first relationship, Añón Higón et al. (2017) used a panel set covering 142 countries between 1995 and 2010. The found that ICT can negatively affect environmental quality as a result of the increasing production of devices, ICT-related machines, and recycling of electronic waste. However, over the medium to long term, ICT can reduce carbon emissions by promoting smart cities, transportation networks, logistics network optimization, and energy consumption saving. They showed that several developed countries have succeeded in reaching the required level of ICT development whereby undesirable effects are reduced significantly.

Asongu (2018) examined the links relating ICTs, globalization, and carbon emissions using 44 African countries over the period 2000-2012, exploring whether ICTs positively interact with globalization to improve environmental sustainability. Using the GMM methodology, the results showed the capability of ICTs to reduce the undesirable impacts of globalization on environment. Similarly, Asongu et al. (2018) investigated the links relating ICTs to $\mathrm{CO}_{2}$. They measured ICTs in terms of internet and mobile phones adoption, and pollution in terms of $\mathrm{CO}_{2}$ emissions. The findings showed that ICTs cannot influence pollution when considering non-interactive estimations. Conversely, based on the interactive regressions, they found a positive effect on environmental damages with regard to the augmentation of $\mathrm{CO}_{2}$ emissions per capita. However, mobile phone technologies positively affect environmental sustainability.

In the same context, Danish et al. (2018) attempted to clarify the relationship between ICTs and 
environmental quality through the interaction of ICTs with GDP and financial development. Using a set of panel models applied on emerging countries over the period 1990-2015, they found some interesting results: (i) ICTs, GDP and financial development positively affect $\mathrm{CO}_{2}$ emissions; (ii) the interaction of ICT with GDP is able to decrease environmental damages; and (iii) the association of ICT and finance negatively affects environment. In terms of public policy, the authors suggested the application of green-ICT approach into the financial sector in order to decrease environmental damages. In the same context, Park et al. (2018) examined whether ICT, globalization (i.e. trade and financial development), and GDP affect environmental degradation using a sample of some European countries between 2001 and 2014. They found that ICT has a long-run relationship with pollution. However, while electricity use increases the level of pollution in European countries, GDP and financial development positively affect the environment. The results broadly show that European countries have not yet attained the required threshold for adopting green ICTs.

To understand the relationship between ICTs and freight transport, Chatti (2020) investigated whether ICT interacts with road freight transport to dampen the potential negative effects on the environment. Indeed, the adoption of fixed and mobile phones in transport activity can reduce $\mathrm{CO}_{2}$ emissions more than internet use. These new technologies are able to decrease $\mathrm{CO}_{2}$ emissions by $2.26 \%$ and $0.85 \%$, respectively. However, using a set of control variables, the adoption of mobile phone technology in freight activity appears more appropriate in terms of pollution reduction than the use of telephone and internet. Indeed, ICTs can be considered a solution for reducing pollution, especially where interacting with road freight transport to increase energy efficiency (i.e. facilitating smart transport and software systems, and electronic marketplaces). Therefore, ICTs can also decrease energy consumption, and thus improve environmental driving practices.

Other works also attempted to identify various practical options in order to reduce pollution that is generated by transportation. Fuchs (2008) examined how ICTs affect environmental quality by discussing the role of telework in reducing pollution. Using ICTs for professional purposes traditionally conducted by people going to particular places ipso facto can reduce the need for travelling, and thus the negative environmental impacts of moving goods and people (Alakeson et al. 2003). Similar effects arise when people and businesses choose to avoid unnecessary travelling and use greener modes of transportation. Actually, ICTs facilitate social relationships by 
connecting both people and businesses. Some experts suggest the use of teleworking and teleconferencing as good options for reducing physical contacts, hence reducing $\mathrm{CO}_{2}$ emissions.

Wang et al. (2015) investigated whether ICT contributes to decreasing $\mathrm{CO}_{2}$ emissions generated by road freight transport. Based on some case studies covering three UK grocery retailers, they found that ICT improves environmental outcomes, and they proposed some ways to decrease emissions by reduced energy consumption. Firstly, transport companies can optimize logistics operations by adopting advanced ICTs to reduce environmental damages caused by road freight transport environmental outcomes, given that $6 \%$ of atmospheric pollution is mainly caused by road freight transport (McKinnon 2010). Several new applications (e-ticketing, smart transport, and reservations) are gaining popularity in this regard, helping companies better identify the most efficient combinations of networks with lower energy demand, thereby enhancing good practices for a more sustainable freight system (Agheli and Hashemi 2018; Centobelli et al. 2020a, 2020b; Tsakalidis et al. 2020).

In the same context, Tacken et al. (2013) provided some solutions to improve environmental performance in the German logistics service sector, including the promotion of some practices such as intermodality, logistics optimization, adaptability of vehicles, and fuel efficiency solutions. Santos (2017) recognized the application of short-term tax incentives and subsidizes, and longterm innovation to reduce GHG emissions from road transport. Llano et al. (2018) showed the importance of intermodality (road/rail) on environmental sustainability in Spain. Promoting intermodality in freight transport appears (among other options) to be a good solution for more efficient and sustainable transport systems. In the literature, we find also some other papers that attempted to examine the links between ICTs and supply chain management and logistics. Oláh et al. (2017) examined the links between the use of new technologies and the performance of logistic service providers (LSPs) in Hungary. The adoption of new technologies especially in logistic activities positively affects the profitability of companies. Centobelli et al. (2020a, 2020b) also highlighted the key role that can be played by green practices and ICTs in order to help companies acting in freight and logistics service. The use of innovative practices and technologies in addition to some supporting policies is able to reach sustainable development objectives. 


\section{Methodology}

\subsection{Data}

We examine whether information technology interacts with freight transportation to improve environmental quality through the reduction of carbon emissions. To reach this goal, we employ a strongly balanced panel data comprising 43 countries $^{1}$ between $_{2002}$ and 2014. The chosen economies and time frame are dictated by the availability of dataset. The dependent variable is defined in terms of carbon emissions derived from liquid energy. ICTs are indexed by the variables internet, mobile phones, and fixed telephone networks, as used by numerous previous researchers, including Asongu et al. (2019). We integrate also four control variables ${ }^{2}$. Table 1 defines all variables. Table 2 reports descriptive statistics. Table 3 presents correlations which may relate variables to each other. Here, it should be noted that the existence of multicollinearity issues is less significant when using interactive estimations (Brambor et al. 2006).

Table 4 shows the stationarity properties of all variables using Levin-Lin-Chu test (LLC 2002) and Im-Pesaran-Shin unit root test (IPS 2003). Despite the fact that LLC unit root test is considered less efficient for smaller samples, it takes into account the heterogeneity of sections. The main advantage of using IPS unit root test is related to its ability to perform in small samples by considering the heterogeneity between them, whereby it eliminates serial correlation.

The acceptance of the null hypothesis (H0) indicates that series are not stationary, whereas the alternative hypothesis confirms the stationarity of different series. To decide between the acceptance and the rejection of the null hypothesis, the p-value level can be compared with the threshold of $10 \%$. Considering the empirical specification related to ICTs, road freight transport, and $\mathrm{CO}_{2}$ emissions, the reported results confirm the stationarity of most variables except mobile phone and telephone adoption, which become stationary at the first difference. For the two other empirical specifications related to rail and inland freight transport, we find the same results in

\footnotetext{
${ }^{1}$ The 43 countries are: Armenia, Australia, Austria, Azerbaijan, Belgium, Bulgaria, Canada, China, Croatia, Czech Republic, Denmark, Estonia, Finland, France, Germany, Greece, Hungary, Iceland, India, Ireland, Italy, Japan, Latvia, Lithuania, Luxembourg, Mexico, Moldova, Netherlands, New Zealand, Norway, Poland, Portugal, Romania, Russia, Slovak Republic, Slovenia, South Korea, Spain, Sweden, Switzerland, Turkey, United Kingdom, and United States. ${ }^{2}$ We include four control variables in the first estimation (Table 5) related to the empirical links between ICTs, road freight transport and carbon emissions. For the other estimations (Table 6, 7 and 8), only three control variables are considered, such as population growth, regulation, and trade openness.
} 
terms of stationarity. Concerning the empirical specification related to ICTs, air freight transport, and $\mathrm{CO}_{2}$ emissions, most variables are stationary, except air freight transport, which becomes stationary only at the first difference.

Table 1. Variable definitions

\begin{tabular}{|l|l|c|}
\hline Variables & Definitions & Sources \\
\hline CO2liq & $\mathrm{CO}_{2}$ emissions from liquid fuel consumption & WDI \\
\hline INT & Internet users per 100 inhabitants & WDI \\
\hline MOB & Mobile phone subscriptions per 100 inhabitants & WDI \\
\hline TEL & Telephone landline subscriptions per 100 inhabitants & WDI \\
\hline GDPg & Per capita GDP growth rate & WDI \\
\hline POPg & Population growth rate & WDI \\
\hline REG & Regulation quality & WDI \\
\hline TO & Imports + exports of goods and services $(\%$ of GDP) & WDI \\
\hline RdFT & Road freight transport in million ton-km & OECD \\
\hline IFT & Inland freight transport (road/rail) in million ton-km & OECD \\
\hline RFT & Rail freight transport in million ton-km & OECD \\
\hline AFT & Air freight transport in million ton-km & OECD \\
\hline
\end{tabular}

Note: $\mathrm{WDI}=$ World Development Indicators

Table 2. Descriptive statistics

\begin{tabular}{|l|l|l|l|l|l|}
\hline & Obs. & Mean & S.D. & Min. & Max. \\
\hline CO2liq & 559 & 164066.3 & 372406.3 & 817.741 & 2446414 \\
\hline INT & 559 & 57.173 & 25.4099 & 1.537 & 98.16 \\
\hline MOB & 559 & 97.680 & 32.846 & 1.192 & 172.178 \\
\hline TEL & 559 & 38.883 & 15.498 & 2.083 & 74.616 \\
\hline GDPg & 559 & 2.488 & 4.505 & -14.559 & 32.997 \\
\hline POPg & 559 & 0.417 & 0.803 & -2.258 & 2.890 \\
\hline REG & 559 & 1.017 & 0.667 & -0.706 & 1.970 \\
\hline TO & 559 & 91.524 & 51.458 & 20.685 & 392.804 \\
\hline RdFT & 559 & 245501.8 & 759892.6 & 182 & 5953486 \\
\hline IFT & 546 & 569113.4 & 1700150 & 660 & $1.26 \mathrm{e}+07$ \\
\hline RFT & 533 & 206012.6 & 604413 & 79 & 2946579 \\
\hline AFT & 494 & 2979.86 & 6526.961 & 0 & 40617.74 \\
\hline
\end{tabular}

Note: S.D. $=$ Standard Deviation. Obs. $=$ Observations 
Table 3. Correlation matrix

\begin{tabular}{|c|c|c|c|c|c|c|c|c|c|}
\hline & CO2liq & INT & MOB & TEL & GDPg & POPg & REG & TO & RdFT \\
\hline CO2liq & 1 & & & & & & & & \\
\hline INT & $\begin{array}{l}-0.0203 \\
(0.6317)\end{array}$ & 1 & & & & & & & \\
\hline МOB & $\begin{array}{l}-0.1503 * * * \\
(0.0004)\end{array}$ & $\begin{array}{l}0.6385^{* * *} * \\
(0.0000)\end{array}$ & 1 & & & & & & \\
\hline TEL & $\begin{array}{l}0.1605^{* * *} \\
(0.0001)\end{array}$ & $\begin{array}{l}0.5409 * * * \\
(0.0000)\end{array}$ & $\begin{array}{l}0.1942 * * * \\
(0.0000)\end{array}$ & 1 & & & & & \\
\hline GDPg & $\begin{array}{l}-0.1192 * \\
(0.0048)\end{array}$ & $\begin{array}{l}-0.4442^{*} \\
(0.0000)\end{array}$ & $\begin{array}{l}-0.4057 * * * \\
(0.0000)\end{array}$ & $\begin{array}{l}-0.3415^{* * *} \\
(0.0000)\end{array}$ & 1 & & & & \\
\hline POPg & $\begin{array}{l}0.3143 * \\
(0.0000)\end{array}$ & $\begin{array}{l}0.1572 * \\
(0.0000)\end{array}$ & $\begin{array}{l}-0.0967^{* *} \\
(0.0222)\end{array}$ & $\begin{array}{l}0.1953^{* * *} * \\
(0.0000)\end{array}$ & $\begin{array}{l}-0.1576^{* * *} \\
(0.0002)\end{array}$ & 1 & & & \\
\hline REG & $\begin{array}{l}-0.0151 \\
(0.7218)\end{array}$ & $\begin{array}{l}0.7312 * \\
(0.0000)\end{array}$ & $\begin{array}{l}0.4356^{* * *} \\
(0.0000)\end{array}$ & $\begin{array}{l}0.6650 * * * \\
(0.0000)\end{array}$ & $\begin{array}{l}-0.3886^{* * *} \\
(0.0000)\end{array}$ & $\begin{array}{l}0.1826 * * * \\
(0.0000)\end{array}$ & 1 & & \\
\hline TO & $\begin{array}{l}-0.5279 \\
(0.0000)\end{array}$ & $\begin{array}{l}0.2292 * \\
(0.0000)\end{array}$ & $\begin{array}{l}0.3035^{*} \\
(0.0000)\end{array}$ & $\begin{array}{l}0.0175 \\
(0.6801)\end{array}$ & $\begin{array}{l}0.0159 \\
(0.7068)\end{array}$ & $\begin{array}{l}-0.0098 \\
(0.8179)\end{array}$ & $\begin{array}{l}0.2133 * * * \\
(0.0000)\end{array}$ & 1 & \\
\hline RdFT & $\begin{array}{l}0.9302 * \\
(0.0000)\end{array}$ & $\begin{array}{l}-0.0595 \\
(0.1604)\end{array}$ & $\begin{array}{l}-0.1070 * * \\
(0.0113)\end{array}$ & $\begin{array}{l}-0.0234 \\
(0.5813)\end{array}$ & $\begin{array}{l}-0.0544 \\
(0.1987)\end{array}$ & $\begin{array}{l}0.2286 * * * \\
(0.0000)\end{array}$ & $\begin{array}{l}-0.0673 \\
(0.1121)\end{array}$ & $\begin{array}{l}-0.4549 * * * \\
(0.0000)\end{array}$ & 1 \\
\hline
\end{tabular}

Note: P-values in parentheses.

***Significant at 1\%.* Significant at 5\%. * Significant at 10\%.

Table 4. Unit root tests

\begin{tabular}{|c|c|c|c|c|}
\hline & \multicolumn{2}{|c|}{ Levin-Lin-Chu test (LLC) } & \multicolumn{2}{|c|}{ Im-Pesaran-Shin test (IPS) } \\
\hline & Level & $\operatorname{Diff}(1)$ & Level & $\operatorname{Diff}(1)$ \\
\hline \multirow[b]{2}{*}{ Ln CO2liq } & $-8.6422 * * *$ & & $-5.1210^{* * *}$ & \\
\hline & $(0.0000)$ & & $(0.0000)$ & \\
\hline \multirow[b]{2}{*}{ INT } & $-8.8060 * * *$ & & $-3.0935^{* * *}$ & \\
\hline & $(0.0000)$ & & $(0.0010)$ & \\
\hline \multirow[b]{2}{*}{ MOB } & $-7.2098 * * *$ & & 0.7854 & $-2.4949 * * *$ \\
\hline & $(0.0000)$ & & $(0.7839)$ & $(0.0063)$ \\
\hline \multirow[b]{2}{*}{ TEL } & $-4.0727 * * *$ & & 3.0100 & $-4.5465 * * *$ \\
\hline & $(0.0000)$ & & $(0.9987)$ & $(0.0000)$ \\
\hline \multirow[b]{2}{*}{ GDPg } & $-10.0562 * * *$ & & $-7.0887 * * *$ & \\
\hline & $(0.0000)$ & & $(0.0000)$ & \\
\hline \multirow[b]{2}{*}{ POPg } & $-20.0123 * * *$ & & $-2.6722 * * *$ & \\
\hline & $(0.0000)$ & & $(0.0038)$ & \\
\hline \multirow[b]{2}{*}{ REG } & $-5.4250 * * *$ & & $-4.6755^{* * *}$ & \\
\hline & $(0.0000)$ & & $(0.0000)$ & \\
\hline \multirow[b]{2}{*}{ TO } & $-8.1422 * * *$ & & $-5.3435^{* * *}$ & \\
\hline & $(0.0000)$ & & $(0.0000)$ & \\
\hline \multirow{2}{*}{ Ln RdFT } & $-10.2095 * * *$ & & $-3.3826^{* * *}$ & \\
\hline & $(0.0000)$ & & $(0.0004)$ & \\
\hline
\end{tabular}

Note: Estimated p-values are in parentheses.

$* * *$ Significant at $1 \%$. ** Significant at 5\%. *Significant at 10\%. 


\subsection{Empirical strategy}

In order to understand how ICTs influence environmental quality, we employ the two-step GMM methodology as proposed by Chatti (2020). The empirical choice is motivated by five reasons: (i) the number of groups $(\mathrm{n}=43)$ exceeds the time periods $(\mathrm{t}=13)$; (ii) the dependent variable (lnCO2liq) does not change, given that the coefficient of first lag variable is larger than 0.8; (iii) the empirical investigation considers an eventual endogeneity bias, using instruments and timeinvariant omitted variables; (iv) "inherent biases in the difference estimator are corrected with the system estimator" (Asongu 2018); and (v) given that the empirical strategy is based on panel dataset, differences across groups are considered in estimations.

We use the extension developed by Roodman $(2009)^{3}$ in order to control the number of instruments, and consider any eventual dependence between sections ${ }^{4}$ (Boateng et al. 2016). The used two-step GMM strategy is "represented by the following system of two equations in level and first difference (respectively), in which the error term takes a two-way error component form" (Asongu 2018).

$$
\begin{aligned}
& {\operatorname{lnCO} 2 l i q_{i, t}}_{1}=\alpha_{0}+\alpha_{1} \operatorname{lnCO2} 2 \operatorname{liq}_{i, t-r}+\alpha_{2} \operatorname{lnFT} T_{i, t}+\alpha_{3} I C T_{i, t}+\alpha_{4} \ln (I C T . F T)_{i, t} \\
& +\sum_{n=1}^{4} \delta_{n} W_{n, i, t-r}+\gamma_{i}+\mu_{t}+\varepsilon_{i, t}
\end{aligned}
$$

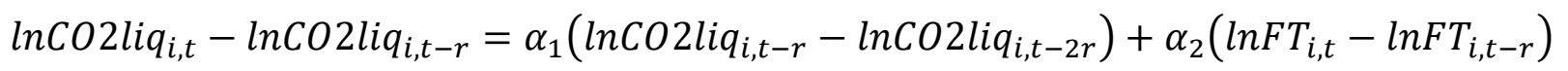

$$
\begin{aligned}
& +\alpha_{3}\left(I C T_{i, t}-I C T_{i, t-r}\right)+\alpha_{4}\left(\operatorname{lnICT} . F T_{i, t}-\operatorname{lnICT} . F T_{i, t-r}\right) \\
& +\sum_{n=1}^{4} \delta_{n}\left(W_{n, i, t-r}-W_{n, i, t-2 r}\right)+\left(\mu_{t}-\mu_{t-r}\right)+\varepsilon_{i, t-r}
\end{aligned}
$$

where $\operatorname{lnCO} 2 \mathrm{liq}_{i, t}$ represents carbon emissions for country $i$ at year $t, \alpha_{0}$ is the constant, $\operatorname{lnFT}$ is the quantity of merchandise loaded by each transport mode, ICT is the communication

\footnotetext{
${ }^{3}$ The lagged levels developed by Arrelano and Bond (1991) cannot serve as "instruments for first differenced variables, particularly if the variables are close to a random walk" (Roodman 2009, p. 114). To tackle this issue, we used the Arrelano-Bover (1995) methodology, extending the Arrelano-Bond estimator to include a new assumption: "those first differences of instrument variables are uncorrelated with the fixed effects" (Roodman 2009, p. 86). Consequently, this consideration enables the "inclusion of more instruments", thereby improving estimates.

${ }^{4}$ Baltagi (2008).
} 
technology, $\ln (I C T . F T)$ indicates the association between ICT and freight transportation by mode, $W$ incorporates four independent variables, $r$ equals one (indicating the coefficient of autoregression), $\mu_{t}$ is the time-specific constant, $\gamma_{i}$ is the country effect, and $\varepsilon_{i, t}$ is the error term.

The dependent variable depends on a set of independent variables (i.e. ICT, FT, POPg, GDPg, TO, and $R E G$ ). The main variables that can affect environmental quality have been highlighted by several studies (e.g. Omri et al. 2015). Therefore, freight transport is expected to be associated with negative environmental effects (Wang et al. 2015; Saidi and Hammami 2017; Chatti 2020). The most egregious of these for macroeconomic analysis are carbon emissions (although localized air pollution is also a major issue), GDP per capita and population growth, whereas regulation is expected to reduce pollution (Asongu et al. 2018).

\section{Results and discussion}

Two empirical specifications are considered in the estimations: without and with control variables (i.e. GDP per capita, population, regulation quality, and trade openness). Within each empirical specification, we consider three specifications in relation to road transportation. Moreover, each sub-specification is characterized in terms of different ICT technology. As used in several works, we utilize two tests to insure that the empirical strategy is appropriate: the test of $\operatorname{AR}(2)$ and the Hansen $J$-test. These tests indicate that the null hypothesis confirms the absence of correlation between instruments and error term, and the excluded instruments are not taken into account in the regressions. In addition, we show the Arrelano and Bond (1991) test, namely $\operatorname{AR}(2)$, "where the null hypothesis $(\mathrm{H} 0)$ indicates that the differenced errors are auto-correlated, since the regression errors are not dependent and equally distributed" (Chatti 2020, p. 129). The AR(2) test is "not robust" and is "weakened by instruments", while the Hansen $J$-test is robust, but is also weakened by instruments. This latter is adopted to restrict the increase of instruments. ${ }^{5}$

Table 5 shows that ICTs positively affect $\mathrm{CO}_{2}$ emissions in both empirical specifications. This result affirms earlier findings by Asongu et al. (2019) and Chatti (2020). According to Añón Higón et al. (2017) and Majeed (2018), ICTs can negatively affect environmental quality due to the

\footnotetext{
${ }^{5}$ To avoid the proliferation of instruments, the total instruments in chosen sub-empirical specifications should be lower than the number of groups.
} 
increasing production of devices, ICT-related machines, and recycling of electronic waste. However, the interaction between ICTs and road freight transportation has a positive environmental effect, as confirmed by McKinnon (2010) and Wang et al. (2015). ICTs are able to reduce environmental damages generated by road freight activity.

According to the first specification, without a conditioning information set, a $10 \%$ increase in the interaction $M O B^{*} R d F T$ can decrease carbon emissions by $2.29 \%$. Specifically, a $10 \%$ increase in the interaction $I N T^{*} R d F T$ reduces environmental degradation by $1.41 \%$. Moreover, the magnitude of -0.253 signifies that a $10 \%$ increase in the interaction $T E L * R d F T$ will reduce pollution by $2.53 \%$. It is worth mentioning that the interaction between telephone technology and road freight transport $\left(T E L^{*} R d F T\right)$ is more efficient in reducing $\mathrm{CO}_{2}$ emissions than the other associations (INT*RdFT and $M O B^{*} R d F T$ ). In addition, the results further show that road freight transportation causes increased $\mathrm{CO}_{2}$ emissions. These results corroborate those presented by Saidi and Hammami (2017) who found a positive impact of road freight activity on environmental degradation.

When considering control variables, we find the same positive relationship between ICTs and carbon emissions. Moreover, the interactions $M O B^{*} R d F T$ and TEL*RdFT cause decreased pollution, and hence improved environmental sustainability. The coefficients of -0.203 and -0.263 mean that a $10 \%$ increase in $M O B * R d F T$ and $T E L * R d F T$ involves respectively around $2.03 \%$ and $2.63 \%$ decreased environmental damages. In addition, the variable RdFT positively affects (i.e. increases) carbon emissions. The magnitudes of 0.187 and 0.251 imply that a $10 \%$ increase RdFT will increase $\mathrm{CO}_{2}$ emissions by $1.87 \%$ and $2.51 \%$, respectively. 
Table 5. ICTs, road transportation, and carbon emissions

\begin{tabular}{|c|c|c|c|c|c|c|}
\hline \multirow[t]{4}{*}{ Variables } & \multicolumn{6}{|l|}{ CO2liq } \\
\hline & \multicolumn{6}{|c|}{ Road Freight Transportation $(R d F T)$} \\
\hline & \multicolumn{3}{|c|}{ Without Conditioning Information } & \multicolumn{3}{|c|}{ With Conditioning Information } \\
\hline & MOB & INT & TEL & MOB & INT & TEL \\
\hline Constant & $\begin{array}{l}0.860 * * * \\
(0.000)\end{array}$ & \begin{tabular}{|l|}
$0.475 * *$ \\
$(0.032)$ \\
\end{tabular} & $\begin{array}{l}0.657 * * * \\
(0.000)\end{array}$ & $\begin{array}{l}0.741 * * \\
(0.010) \\
\end{array}$ & \begin{tabular}{|l|}
0.335 \\
$(0.210)$ \\
\end{tabular} & $\begin{array}{l}0.679 \text { *** } \\
(0.003)\end{array}$ \\
\hline Ln CO2liq (-1) & $\begin{array}{l}1.017 * * * \\
(0.000)\end{array}$ & \begin{tabular}{|l|}
$0.995 * * *$ \\
$(0.000)$ \\
\end{tabular} & $\begin{array}{l}1.006^{* * *} \\
(0.000)\end{array}$ & $\begin{array}{l}1.008 * * * \\
(0.000)\end{array}$ & $\begin{array}{l}0.998^{* * *} \\
(0.000) \\
\end{array}$ & $\begin{array}{l}1.009 * * * \\
(0.000)\end{array}$ \\
\hline Internet & & \begin{tabular}{|l|}
$0.002 * *$ \\
$(0.021)$ \\
\end{tabular} & & & $\begin{array}{l}0.002^{*} \\
(0.062)\end{array}$ & \\
\hline Mobile & $\begin{array}{l}0.002 * * * \\
(0.005)\end{array}$ & & & $\begin{array}{l}0.002 * * \\
(0.017)\end{array}$ & & \\
\hline Telephone & & & $\begin{array}{l}0.007 * * * \\
(0.003)\end{array}$ & & & $\begin{array}{l}0.006^{*} \\
(0.072)\end{array}$ \\
\hline Ln RdFT & $\begin{array}{l}0.204 * * * \\
(0.000)\end{array}$ & \begin{tabular}{|l|}
$0.138^{*}$ \\
$(0.051)$
\end{tabular} & $\begin{array}{l}0.242^{* * *} \\
(0.002)\end{array}$ & $\begin{array}{l}0.187 * * \\
(0.010)\end{array}$ & $\begin{array}{l}0.124 \\
(0.151)\end{array}$ & $\begin{array}{l}0.251^{* *} \\
(0.014)\end{array}$ \\
\hline Ln INT*RdFT & & $\begin{array}{l}-0.141^{* *} \\
(0.026)\end{array}$ & & & $\begin{array}{l}-0.124 \\
(0.131)\end{array}$ & \\
\hline Ln MOB*RdFT & $\begin{array}{l}-0.229 * * * \\
(0.001)\end{array}$ & & & $\begin{array}{l}-0.203 * * \\
(0.011) \\
\end{array}$ & & \\
\hline Ln TEL*RdFT & & & $\begin{array}{l}-0.253 * * * \\
(0.002)\end{array}$ & & & $\begin{array}{l}-0.263^{* *} \\
(0.017)\end{array}$ \\
\hline POP growth & & & & $\begin{array}{l}0.035^{*} \\
(0.064)\end{array}$ & & $\begin{array}{l}0.011 \\
(0.634)\end{array}$ \\
\hline Regulation & & & & $\begin{array}{l}-0.016 \\
(0.444)\end{array}$ & $\begin{array}{l}-0.022 \\
(0.195)\end{array}$ & $\begin{array}{l}0.005 \\
(0.686)\end{array}$ \\
\hline Trade & & & & $\begin{array}{l}-0.00004 \\
(0.841)\end{array}$ & $\begin{array}{l}-0.00007 \\
(0.684)\end{array}$ & $\begin{array}{l}0.00003 \\
(0.827)\end{array}$ \\
\hline GDP growth & & & & $\begin{array}{l}0.001 \\
(0.509)\end{array}$ & $\begin{array}{l}0.004^{* * *} \\
(0.001)\end{array}$ & $\begin{array}{l}0.0002 \\
(0.860)\end{array}$ \\
\hline $\mathrm{AR}(2)$ test & $(0.477)$ & $(0.495)$ & $(0.123)$ & $(0.338)$ & $(0.289)$ & $(0.113)$ \\
\hline Hansen $J$-test & $(0.355)$ & $(0.255)$ & $(0.362)$ & $(0.353)$ & $(0.623)$ & $(0.345)$ \\
\hline Instruments & 39 & 39 & 39 & 39 & 39 & 39 \\
\hline Groups & 43 & 43 & 43 & 43 & 43 & 43 \\
\hline Obs. & 516 & 516 & 516 & 516 & 516 & 516 \\
\hline
\end{tabular}

P-values in brackets.

$*, * *, * * *$ significant at $10 \%, 5 \%$ and $1 \%$, respectively

Table 6 reports the findings related to ICTs, inland freight transport, and carbon emissions. In this estimation, we use only three control variables: population growth, regulation, and trade openness. The results show that ICTs positively affect carbon emissions, similar to findings reported by Asongu et al. (2019), Chatti (2020) and Su et al. (2021). This is due essentially to their great dependency on electricity consumption in relation to the provision of equipment and devices, and 
the use of related infrastructures. The contribution of ICTs to global $\mathrm{CO}_{2}$ emissions has been estimated to be $2 \%$ (Mingay 2007).

However, the results show that the interaction between ICTs and inland freight transport (roadrail) negatively affects carbon emissions. The coefficient of -0.236 shows that environmental degradation can be reduced by $2.36 \%$ if the interaction $M O B * I F T$ improves by $10 \%$. The coefficient of -0.127 indicates that a $10 \%$ increase in the interaction $I N T^{*} I F T$ is able to decrease pollution by $1.27 \%$. It is worth noting that the interaction $T E L$ *IFT provides the most efficient and significant effect on environmental quality. Specifically, a $10 \%$ increase in the interaction TEL *IFT decreases carbon emissions by $3.02 \%$. In the same context, Harris et al. (2014) and Llano et al. (2018) showed how the use of ICTs for multimodality ${ }^{6}$ can decrease carbon emissions. Compared with road transport, the use of ICTs in inland freight transport (road-rail) appears less harmful to the environment.

With the inclusion of control variables, the mobile phones and telephone technologies seem to positively affect carbon emissions. The coefficients of 0.227 and 0.294 show that a $10 \%$ increase in $I F T$ will increase environmental degradation by $2.27 \%$ and $2.94 \%$, respectively. However, the interaction $M O B^{*} I F T$ positively affects environmental sustainability. The coefficient of -0.239 indicates that a $10 \%$ increase in the association $M O B^{*} I F T$ will result in a decrease in $\mathrm{CO}_{2}$ emissions of around $2.39 \%$. In addition, the interaction TEL ${ }^{*} I F T$ shows the same positive and significant effect on environmental quality with regard to pollution reductions. More specifically, a $10 \%$ increase in $T E L * I F T$ implies a $2.67 \%$ decrease in the pollution level. The results reinforce the association between multimodality and ICTs to facilitate data exchange and real-time visibility (Harris et al. 2014).

\footnotetext{
${ }^{6}$ Multimodality is defined as transportation activity using at least two modes of transport (e.g. road-rail, road-sea, etc.). Intermodality can be considered as a particular type of multimodality which utilizes the same loading unit, such as a shipping container.
} 
Table 6. ICTs, inland transportation, and carbon emissions

\begin{tabular}{|c|c|c|c|c|c|c|}
\hline \multirow[t]{4}{*}{ Variables } & \multicolumn{6}{|l|}{ CO2liq } \\
\hline & \multicolumn{6}{|c|}{ Inland Freight Transportation (IFT) } \\
\hline & \multicolumn{3}{|c|}{ Without Conditioning Information } & \multicolumn{3}{|c|}{ With Conditioning Information } \\
\hline & MOB & INT & TEL & MOB & INT & TEL \\
\hline Constant & $\begin{array}{l}0.913 * * * \\
(0.000)\end{array}$ & $\begin{array}{l}0.427 * * \\
(0.020)\end{array}$ & $\begin{array}{l}0.624 * * \\
(0.030)\end{array}$ & $\begin{array}{l}0.919 * * * \\
(0.000)\end{array}$ & $\begin{array}{l}0.602 \\
(0.217)\end{array}$ & $\begin{array}{l}0.612^{* *} \\
(0.022)\end{array}$ \\
\hline Ln CO2liq (-1) & $\begin{array}{l}0.997 * * * \\
(0.000)\end{array}$ & $\begin{array}{l}0.994 * * * \\
(0.000)\end{array}$ & $\begin{array}{l}0.962^{* * *} \\
(0.000)\end{array}$ & $\begin{array}{l}1.000 * * * \\
(0.000)\end{array}$ & $\begin{array}{l}0.979 * * * \\
(0.000)\end{array}$ & $\begin{array}{l}0.971 * * * \\
(0.000)\end{array}$ \\
\hline Internet & & $\begin{array}{l}0.001^{*} \\
(0.096)\end{array}$ & & & $\begin{array}{l}0.003 \\
(0.141)\end{array}$ & \\
\hline Mobile & $\begin{array}{l}0.002 * * * \\
(0.004)\end{array}$ & & & $\begin{array}{l}0.002 * * \\
(0.021)\end{array}$ & & \\
\hline Telephone & & & $\begin{array}{l}0.010 * * \\
(0.024)\end{array}$ & & & $\begin{array}{l}0.008^{*} \\
(0.076)\end{array}$ \\
\hline Ln IFT & $\begin{array}{l}0.230 * * * \\
(0.000)\end{array}$ & $\begin{array}{l}0.127^{*} \\
(0.087)\end{array}$ & $\begin{array}{l}0.341 * * \\
(0.023)\end{array}$ & $\begin{array}{l}0.227 * * * \\
(0.000)\end{array}$ & $\begin{array}{l}0.201 \\
(0.251)\end{array}$ & $\begin{array}{l}0.294^{*} \\
(0.057)\end{array}$ \\
\hline Ln INT*IFT & & $\begin{array}{l}-0.127 * * \\
(0.023)\end{array}$ & & & $\begin{array}{l}-0.187 \\
(0.169) \\
\end{array}$ & \\
\hline Ln MOB*IFT & $\begin{array}{l}-0.236 * * * \\
(0.001)\end{array}$ & & & $\begin{array}{l}-0.239 * * * \\
(0.002)\end{array}$ & & \\
\hline Ln TEL*IFT & & & $\begin{array}{l}-0.302 * * \\
(0.039)\end{array}$ & & & $\begin{array}{l}-0.267^{*} \\
(0.063)\end{array}$ \\
\hline POP growth & & & & $\begin{array}{l}0.020 \\
(0.341)\end{array}$ & $\begin{array}{l}0.034 \\
(0.140)\end{array}$ & $\begin{array}{l}0.026 \\
(0.311)\end{array}$ \\
\hline Regulation & & & & $\begin{array}{l}-0.002 \\
(0.916)\end{array}$ & $\begin{array}{l}-0.017 \\
(0.518)\end{array}$ & $\begin{array}{l}-0.015 \\
(0.460)\end{array}$ \\
\hline Trade & & & & $\begin{array}{l}0.0001 \\
(0.700)\end{array}$ & $\begin{array}{l}-0.00005 \\
(0.839)\end{array}$ & $\begin{array}{l}-0.0001 \\
(0.606)\end{array}$ \\
\hline $\mathrm{AR}(2)$ test & $(0.471)$ & $(0.488)$ & $(0.321)$ & $(0.484)$ & $(0.472)$ & $(0.336)$ \\
\hline Hansen $J$-test & $(0.327)$ & $(0.308)$ & $(0.537)$ & $(0.530)$ & $(0.270)$ & $(0.482)$ \\
\hline Instruments & 40 & 40 & 40 & 39 & 39 & 39 \\
\hline Groups & 42 & 42 & 42 & 42 & 42 & 42 \\
\hline Obs. & 504 & 504 & 504 & 504 & 504 & 504 \\
\hline
\end{tabular}

P-values in brackets.

$*, * *, * * *$ significant at $10 \%, 5 \%$ and $1 \%$, respectively

Table 7 reports the findings in relation with ICTs, air freight transport, and $\mathrm{CO}_{2}$ emissions. Based on the first empirical specification without control variables, air freight transport positively affects (i.e. increases) environmental damage. The magnitudes of $0.157,0.107$ and 0.198 imply that a $10 \%$ increase in air freight transport may increase carbon emissions by $1.57 \%, 1.07 \%$, and 1.98\%, respectively. However, the interactions $I N T^{*} A F T, M O B^{*} A F T$ and $T E L^{*} A F T$ seem to have 
negative effects on carbon emissions, which indicates that increasing ICT adoption in air freight transportation will accelerate its positive impact on environmental quality.

Table 7. ICTs, air transportation, and carbon emissions

\begin{tabular}{|c|c|c|c|c|c|c|}
\hline \multirow[t]{4}{*}{ Variables } & \multicolumn{6}{|l|}{ CO2liq } \\
\hline & \multicolumn{6}{|c|}{ Air Freight Transportation (AFT) } \\
\hline & \multicolumn{3}{|c|}{ Without Conditioning Information } & \multicolumn{3}{|c|}{ With Conditioning Information } \\
\hline & MOB & INT & TEL & MOB & INT & TEL \\
\hline Constant & $\begin{array}{l}0.588^{* *} \\
(0.034) \\
\end{array}$ & $\begin{array}{l}0.335^{* *} \\
(0.035)\end{array}$ & $\begin{array}{l}0.546^{*} \\
(0.075)\end{array}$ & $\begin{array}{l}0.608 * * \\
(0.031) \\
\end{array}$ & $\begin{array}{l}0.383^{*} \\
(0.075)\end{array}$ & $\begin{array}{l}0.636 \\
(0.231)\end{array}$ \\
\hline Ln CO2liq (-1) & $\begin{array}{l}0.990 * * * \\
(0.000)\end{array}$ & $\begin{array}{l}0.993 * * * \\
(0.000)\end{array}$ & $\begin{array}{l}0.993 * * * \\
(0.000)\end{array}$ & $\begin{array}{l}0.990 * * * \\
(0.000)\end{array}$ & $\begin{array}{l}1.003 * * * \\
(0.000)\end{array}$ & $\begin{array}{l}0.999 * * * \\
(0.000)\end{array}$ \\
\hline Internet & & $\begin{array}{l}0.001 \\
(0.182)\end{array}$ & & & $\begin{array}{l}0.003^{*} \\
(0.068)\end{array}$ & \\
\hline Mobile & $\begin{array}{l}0.001 \\
(0.102)\end{array}$ & & & $\begin{array}{l}0.001 \\
(0.179)\end{array}$ & & \\
\hline Telephone & & & $\begin{array}{l}0.005 \\
(0.142)\end{array}$ & & & $\begin{array}{l}0.006 \\
(0.369)\end{array}$ \\
\hline Ln AFT & $\begin{array}{l}0.157 * * \\
(0.041)\end{array}$ & $\begin{array}{l}0.107 * * \\
(0.069) \\
\end{array}$ & $\begin{array}{l}0.198^{*} \\
(0.093)\end{array}$ & $\begin{array}{l}0.163^{*} \\
(0.054) \\
\end{array}$ & $\begin{array}{l}0.160^{*} \\
(0.071) \\
\end{array}$ & $\begin{array}{l}0.246 \\
(0.289)\end{array}$ \\
\hline Ln INT*AFT & & $\begin{array}{l}-0.104 * \\
(0.079)\end{array}$ & & & $\begin{array}{l}-0.163^{*} \\
(0.082)\end{array}$ & \\
\hline Ln MOB*AFT & $\begin{array}{l}-0.153 * * \\
(0.042)\end{array}$ & & & $\begin{array}{l}-0.158^{* *} \\
(0.054)\end{array}$ & & \\
\hline Ln TEL*AFT & & & $\begin{array}{l}-0.197^{*} \\
(0.097)\end{array}$ & & & $\begin{array}{l}-0.250 \\
(0.288)\end{array}$ \\
\hline POP growth & & & & $\begin{array}{l}0.016 \\
(0.279)\end{array}$ & $\begin{array}{l}0.029^{*} \\
(0.051)\end{array}$ & $\begin{array}{l}0.023 \\
(0.259)\end{array}$ \\
\hline Regulation & & & & $\begin{array}{l}-0.016 \\
(0.424)\end{array}$ & $\begin{array}{l}-0.018 \\
(0.430)\end{array}$ & $\begin{array}{l}0.006 \\
(0.852)\end{array}$ \\
\hline Trade & & & & $\begin{array}{l}0.00001 \\
(0.935)\end{array}$ & $\begin{array}{l}0.00003 \\
(0.847)\end{array}$ & $\begin{array}{l}0.00009 \\
(0.734)\end{array}$ \\
\hline $\mathrm{AR}(2)$ test & $(0.463)$ & $(0.429)$ & $(0.734)$ & $(0.432)$ & $(0.266)$ & $(0.682)$ \\
\hline Hansen $J$-test & $(0.416)$ & $(0.344)$ & $(0.242)$ & $(0.357)$ & $(0.351)$ & $(0.188)$ \\
\hline Instruments & 34 & 34 & 34 & 35 & 35 & 35 \\
\hline Groups & 38 & 38 & 38 & 38 & 38 & 38 \\
\hline Obs. & 456 & 456 & 456 & 456 & 456 & 456 \\
\hline
\end{tabular}

P-values in brackets.

$*, * *, * * *$ significant at $10 \%, 5 \%$ and $1 \%$, respectively

Considering the second specification, it appears that air freight transportation positively increases carbon emissions. A 10\% increase in air freight activity may increase carbon dioxide emissions by 
$1.63 \%$ and $1.60 \%$, respectively. This suggests that increasing air freight transport undermines environmental sustainability. However, the adoption of ICTs in air transportation can improve environmental quality. In terms of elasticities, the magnitudes of -0.158 and -0.163 note that a $10 \%$ increase in $M O B^{*} A F T$ and $I N T^{*} A F T$ leads respectively to $1.58 \%$ and $1.63 \%$ decreased pollution. These findings are largely supported by several authors who underlined the importance of using internet and mobile phone technologies to reduce $\mathrm{CO}_{2}$ emissions. Using efficient infrastructure networks, ICTs can reduce the need for transportation (see Gutierrez et al., 2009). The simple association of mobile phones with internet technology reduces the need for physical contacts, and thus decreases urban costs. In addition, the adoption of internet applications can be useful for companies' competitiveness, particularly in the air transport sector (Buhalis 2004; Wang et al. 2011; Agheli and Hashemi 2018).

Table 8 presents the findings related to ICTs, rail freight transport, and $\mathrm{CO}_{2}$ emissions. The results broadly show the positive impact of RFT on carbon emissions, confirming its negative impact on the environment, reaffirming earlier studies (e.g. Asongu 2019; Chatti 2020). Specifically, the magnitudes of $0.157,0.117$, and 0.207 show that a $10 \%$ increase in rail freight transport may increase pollution by $1.57 \%, 1.17 \%$, and $2.07 \%$, respectively. However, the interaction between ICTs and rail freight transport seems to have a positive impact on environmental sustainability. Firstly, the coefficient of -0.111 reports that a $10 \%$ increase in $I N T^{*} R F T$ will decrease environmental damages by $1.11 \%$. Secondly, the magnitude of -0.155 indicates that a $10 \%$ increase in the interaction $M O B^{*} R F T$ will reduce carbon emissions by $1.55 \%$. Thirdly, the magnitude of 0.194 indicates that a $10 \%$ increase in the interaction $T E L * R F T$ will improve environmental quality by $1.94 \%$. Moreover, the findings further suggest that the association $T E L * R F T$ is more efficient in terms of reducing environmental degradation than the use of internet and mobile phone technologies.

Relative to the second specification, the findings show that rail freight transport positively affects pollution. Specifically, the coefficients of 0.181 and 0.198 imply that a $10 \%$ increase in $R F T$ is able to reduce emissions by $1.81 \%$ and $1.98 \%$ (respectively). However, the adoption of new technology in RFT can improve the environment, with the consideration of $\mathrm{CO}_{2}$ emissions reductions. The magnitudes of -0.162 and -0.191 show that the environmental quality will be increased by $1.62 \%$ and $1.91 \%$ (respectively) if the interactions $M O B * R F T$ and $T E L * R F T$ improve 
by $10 \%$. Moreover, it is worth noting that the combination $I N T * R F T$ does not affect the environment. The findings also illustrate that the adoption of telephone technology in RFT is more efficient in reducing carbon emissions than utilizing internet and mobile phone technologies. The use of new technologies is clearly of importance in the management of organizations, and is seen as a key factor of the integration of supply chain and companies' competitiveness (Cepolina and Ghiara 2013; Molero et al. 2019).

Table 8. ICTs, rail transportation, and carbon emissions

\begin{tabular}{|c|c|c|c|c|c|c|}
\hline \multirow[t]{4}{*}{ Variables } & \multicolumn{6}{|l|}{ CO2liq } \\
\hline & \multicolumn{6}{|c|}{ Rail Freight Transportation (RFT) } \\
\hline & \multicolumn{3}{|c|}{ Without Conditioning Information } & \multicolumn{3}{|c|}{ With Conditioning Information } \\
\hline & MOB & \begin{tabular}{|l|} 
INT \\
\end{tabular} & TEL & MOB & INT & TEL \\
\hline Constant & $\begin{array}{l}0.591 * * * \\
(0.001)\end{array}$ & \begin{tabular}{|l|}
0.324 \\
$(0.106)$
\end{tabular} & $\begin{array}{l}0.454 \\
(0.127)\end{array}$ & $\begin{array}{l}0.708 * * \\
(0.049)\end{array}$ & $\begin{array}{l}0.328 \\
(0.619)\end{array}$ & $\begin{array}{l}0.627^{*} \\
(0.061)\end{array}$ \\
\hline Ln CO2liq (-1) & $\begin{array}{l}0.994 * * * \\
(0.000)\end{array}$ & $\begin{array}{l}0.994 * * * \\
(0.000)\end{array}$ & $\begin{array}{l}0.986^{* * *} \\
(0.000)\end{array}$ & $\begin{array}{l}0.969 * * * \\
(0.000)\end{array}$ & $\begin{array}{l}0.991 * * * \\
(0.000)\end{array}$ & $\begin{array}{l}0.975 * * * \\
(0.000)\end{array}$ \\
\hline Internet & & $\begin{array}{l}0.001^{*} \\
(0.064)\end{array}$ & & & $\begin{array}{l}0.002 \\
(0.248)\end{array}$ & \\
\hline Mobile & $\begin{array}{l}0.001 * * \\
(0.025)\end{array}$ & & & $\begin{array}{l}0.001 \\
(0.115)\end{array}$ & & \\
\hline Telephone & & & $\begin{array}{l}0.006^{* * *} \\
(0.000)\end{array}$ & & & $\begin{array}{l}0.006^{* * *} \\
(0.001)\end{array}$ \\
\hline Ln RFT & $\begin{array}{l}0.157 * * * \\
(0.001)\end{array}$ & \begin{tabular}{|l}
$0.117 * *$ \\
$(0.018)$ \\
\end{tabular} & $\begin{array}{l}0.207 * * * \\
(0.000)\end{array}$ & $\begin{array}{l}0.181 * * \\
(0.03)\end{array}$ & $\begin{array}{l}0.188 \\
(0.202)\end{array}$ & $\begin{array}{l}0.198 * * * \\
(0.001)\end{array}$ \\
\hline Ln INT*RFT & & $\begin{array}{l}-0.111^{* *} \\
(0.021)\end{array}$ & & & $\begin{array}{l}-0.164 \\
(0.238)\end{array}$ & \\
\hline Ln MOB*RFT & $\begin{array}{l}-0.155^{* * * *} \\
(0.002)\end{array}$ & & & $\begin{array}{l}-0.162 * * \\
(0.010)\end{array}$ & & \\
\hline Ln TEL*RFT & & & $\begin{array}{l}-0.194 * * * \\
(0.003)\end{array}$ & & & $\begin{array}{l}-0.191 * * * \\
(0.002)\end{array}$ \\
\hline POP growth & & & & $\begin{array}{l}0.062 * * \\
(0.027)\end{array}$ & $\begin{array}{l}0.035 \\
(0.239)\end{array}$ & $\begin{array}{l}0.034 \\
(0.329)\end{array}$ \\
\hline Regulation & & & & $\begin{array}{l}-0.008 \\
(0.602)\end{array}$ & $\begin{array}{l}-0.011 \\
(0.704)\end{array}$ & $\begin{array}{l}-0.012 \\
(0.697)\end{array}$ \\
\hline Trade & & & & $\begin{array}{l}-0.0001 \\
(0.671)\end{array}$ & $\begin{array}{l}0.0001 \\
(0.724)\end{array}$ & $\begin{array}{l}-0.0002 \\
(0.541)\end{array}$ \\
\hline $\mathrm{AR}(2)$ test & $(0.456)$ & $(0.485)$ & $(0.282)$ & $(0.474)$ & $(0.494)$ & $(0.296)$ \\
\hline Hansen $J$-test & $(0.433)$ & $(0.237)$ & $(0.458)$ & $(0.411)$ & $(0.311)$ & $(0.309)$ \\
\hline Instruments & 34 & 34 & 34 & 39 & 39 & 39 \\
\hline Groups & 41 & 41 & 41 & 41 & 41 & 41 \\
\hline Obs. & 492 & 492 & 492 & 492 & 492 & 492 \\
\hline
\end{tabular}

P-values in brackets.

$*, * *, * * *$ significant at $10 \%, 5 \%$ and $1 \%$, respectively 


\section{Conclusion and policy implications}

This paper investigated whether the interaction between ICTs and freight transport can influence $\mathrm{CO}_{2}$ emissions in 43 countries between 2002 and 2014. ICTs are measured in terms of internet, mobile phones, and telephone adoption, while freight transport is approximated in terms of road, rail, inland, and air freight transport. Using GMM approach, the results suggest some interesting findings: (i) the only use of ICTs and freight transport increase $\mathrm{CO}_{2}$ emissions; (ii) the interaction between ICTs and freight transportation can improve environmental quality with regard to $\mathrm{CO}_{2}$ emissions reduction; (iii) the interaction of telephone and mobile phone technologies with road, rail, and inland freight activities are more efficient in damping environmental degradation than adopting internet technology; (iv) the interaction between telephone and multimodality (i.e. roadrail) can significantly accelerate environmental quality; and (v) the use of internet is the most efficient technology in reducing $\mathrm{CO}_{2}$ emissions where interacting with air freight transport.

In terms of policy implications, the results showed the important role that can be played by ICTs in order to dampen the costs and constraints generated by freight transport activity, which is an egregious cause of pollution. Indeed, a 10\% increase in the association between ICTs and freight transport will reduce environmental degradation by between $1.27 \%$ and $3.02 \%$. Therefore, both policy makers and transport companies could fully profit from the implementation of new ICT solutions for logistics and transportation. Actually, some innovative ICTs integrate big data, artificial intelligence, and internet of things. These breakthrough technologies are crucial to facilitate management, planning, and supply chain applications during the movement of merchandise (Molero et al. 2019). The findings also suggest the importance of adopting ICTs in multimodal transport in order to accelerate environmental sustainability. Specifically, the simple interaction between telephone adoption and inland freight transport can reduce carbon emissions by between $2.39 \%$ and $3.02 \%$.

Finally, this empirical research is the first to explicitly identify the capability of ICTs in reducing environmental degradation when interacting with various modes of transport. This paper also highlights the necessity of applying the appropriate new technology, dependent on each specific mode of transport (i.e. the use of internet for air freight transport). For future research, we plan to consider the heterogeneity across developing and developed countries as proposed by Majeed 
(2018). Indeed, the interaction between ICTs and freight transport could have different effects on environmental sustainability, dependent on the level of development of each group. Moreover, it would be interesting to examine how some new technologies interact with passenger transport activities to reduce pollution, taking into account other pollution indicators (e.g. $\mathrm{CO}_{2}$ intensity, $\mathrm{CO}_{2}$ emissions, etc.).

\section{Conflict of interest}

The author declares that there is no conflict of interest.

\section{References}

Agheli L, Hashemi S. 2018. Impact of Information and Communication Technology on Transport among the Selected Middle East Countries. J Econ Cooperation Dev. 39(1): 1-18.

Alakeson V, Aldrich T, Goodman J, Jorgensen B. 2003. Making the network. Sustainable development in a digital society. Teddington. Forum for the Future.

Añón Higón D, Gholami R, Shirazi F. 2017. ICT and environmental sustainability: a global perspective. Telemat Inform. 34: 85-95.

Arellano M, Bond S. 1991. Some tests of specification for panel data: Monte Carlo evidence and an application to employment equations. Rev Econ Stud. 58(2): 277-297.

Arellano M, Bover O. 1995. Another look at the instrumental variable estimation of errorcomponents models. J Econom. 68(1): 29-51.

Asongu SA, Le Roux S, Biekpe N. 2018. Enhancing ICT for environmental sustainability in SubSaharan Africa. Technol Forecast Soc Change. 127: 209-216.

Asongu SA. 2018. ICT, openness and CO2 emissions in Africa. Environ Sci Pollut Res. 25: 93519359.

Asongu SA, Nwachukwu JC, Pyke C. 2019. The comparative economics of ICT, environmental degradation and inclusive human development in Sub-Saharan Africa. Soc Indic Res. 143: 1271-1297.

Baltagi BH. 2008. Forecasting with panel data. J Forecast. 27: 153-173.

Boateng A, Asongu SA, Akamavi R, Tchamyou VS. 2016. Information Asymmetry and Market Power in the African Banking Industry. African Governance and Development Institute Working Paper No. 16/032, Yaoundé.

Brambor T, Clark WM, Golder M. 2006. Understanding interaction models: improving empirical analyses. Polit Anal. 14(1): 63-82.

Buhalis D. 2004. EAirlines: Strategic and tactical use of ICTS in the airline industry. Inf Manag. 41(7): 805-882.

Centobelli P, Cerchione R, Esposito E. 2020. Pursuing supply chain sustainable development goals through the adoption of green practices and enabling technologies: A cross-country analysis of LSPs. 153(119920): 1-9.

Centobelli P, Cerchione R, Esposito E, Shashi. 2020. Evaluating environmental sustainability strategies in freight transport and logistics industry. Bus Strategy Environ. 29(3), 15631574. 
Chatti W, Ben Soltane B, Abalala T. 2019. Impacts of public transport policy on city size and welfare. Netw Spat Econ. 19(4): 1097-1122.

Chatti W. 2020. Information and communication technologies, road freight transport, and environmental sustainability. Environmental Economics. 11(1): 124-132.

Cucchiella F, Koh L. 2012. Green supply chain: how do carbon management and sustainability development create competitive advantage for the supply chain? Supply Chain Manag. 17(1): 1-4.

Danish Khan N, Baloch MA, Saud S, Fatima T. 2018. The effect of ICT on CO2 emissions in emerging economies: does the level of income matters? Environ Sci Pollut Res. 25: 2285022860.

Fuchs C. 2008. The implications of new information and communication technologies for sustainability. Environ Dev Sustain. 10: 291-309.

Giannopoulos GA. 2004. The application of information and communication technologies in transport. Eur J Oper Res. 152(2): 302-330.

Gutierrez LH, Lee S, Virto, LR. 2009. Market concentration and performance in mobile markets in Africa and Latin America. OECD Development Center (mimeo).

Harris I, Wang Y, Wang H. 2015. ICT in multimodal transport and technological trends: Unleashing potential for the future. Int J Prod Econ. 159: 88-103.

Cepolina S, Ghiara H. 2013. New trends in port strategies. Emerging role for ICT infrastructures. Res Trans Buss Manag. 8: 195-205.

Intergovernmental Panel on Climate Change-IPCC. 2014. Climate Change 2014: Synthesis Report. Contribution of Working Groups I, II and III to the Fifth Assessment Report of the Intergovernmental Panel on Climate Change, [Core Writing Team: R.K. Pachauri and L.A. Meyer (eds.)], IPCC, Geneva, Switzerland.

International Energy Agency. 2016. CO2 emissions from fuel combustion by sector in 2014, in CO2 Emissions from Fuel Combustion, IEA, 2016. In: CO2 highlights 2016-Excel tables. http://www.iea.org/publications/freepublications/publication/CO2-emissions-from-fuelcombustion-highlights-2016.html.

Im KS, Pesaran MH, Shin Y. (2003). Testing for unit root tests in heterogeneous panels. J Econom. 115, 53-74.

Levin A, Lin CF, Chu CSJ. (2002). Unit root test in panel data: asymptotic and finite sample properties. J Econom. 108(1), 1-24.

Llano C, Pérez-Balsalobre S, Pérez-García J. 2018. Greenhouse Gas Emissions from IntraNational Freight Transport: Measurement and Scenarios for Greater Sustainability in Spain. Sustainability. 10: 2467.

Majeed MT. (2018). Information and communication technology (ICT) and environmental sustainability in developed and developing countries. Pakistan Journal of Commerce and Social Sciences. 12(3), 758-783.

Mckinnon A. 2016. Freight Transport in a Low-Carbon World Assessing Opportunities for Cutting Emissions. TR News 306, November-December, 2016

McKinnon AC. 2010. Environmental sustainability: a new priority for logistics managers. In: McKinnon AC, Cullinane S, Browne M, Whiteing A. (Eds), Green Logistics - Improving the Environmental Sustainability of Logistics, Kogan Page, London, pp. 3-22.

Mingay S. 2007. Green IT: the new industry shock wave. Gartner Research, 2007.

Molero GD, Santarremigia FE, Poveda-Reyes S, Mayrhofer M, Awad-Nunez S, Kassabji A. 2019. Key factors for the implementation and integration of innovative ICT solutions in SMEs 
and large companies involved in the multimodal transport of dangerous goods. Eur Trans Res Rev. 11(28): 2-16.

Nilsson FR, Sternberg H. 2017. Who controls transport emissions and who cares? Investigating the monitoring of environmental sustainability from a logistics service provider's perspective. Int J Logist Manag. 28(3): 789-820.

Oláh J, Karmazin G, Pető K, Popp J. 2018. Information technology developments of logistics service providers in Hungary. Int Logist Res Appl. 21(3): 332-344.

Omri A, Daly S, Rault CH, Chaibi A. 2015. Financial development, environmental quality, trade and economic growth: what causes in MENA countries. Energy Econ. 48(C): 242-252.

Ozcan B, Apergis N. 2018. The impact of internet use on air pollution: Evidence from emerging countries. Environ Sci Pollut Res. 25: 4174-4189.

Park Y, Meng F, Baloch MA. 2018. The effect of ICT, financial development, growth, and trade openness on CO2 emissions: an empirical analysis. Environ Sci Pollut Res. 25: 3070830719.

Perego A, Perotti S, Mangiaracina R. 2011. ICT for logistics and freight transportation: a literature review and research agenda. Int J Phys Distrib Logist Manag. 41: 457-483.

Roodman D. 2009. How to do xtabond2: An introduction to difference and system GMM in Stata. Stata J. 9(1): 86-136.

Saidi S, Hammami S. 2017. Modeling the causal linkages between transport, economic growth and environmental degradation for 75 countries. Trans Res Part D. 53: 415-427.

Santos G. 2017. Road transport and CO2 emissions: What are the challenges? Transp Policy. 59: 71-74.

Shahab, S.; Faisal, C.M.N.; Hafeez, M.; Qamri, G.M. Towards Achieving Sustainable Development: Role of Technology Innovation, Technology Adoption and CO2 Emission for BRICS. Int. J. Environ. Res. Public Health 2021, 18, 277.

Tacken J, Sanchez-Rodrigues, V, Mason R. 2013. Examining CO2 reduction within the German logistics sector. Int J Logist Manag. 25(1): 54-84.

Tob-Ogua A, Kumarb N, Cullena J. 2018. ICT adoption in road freight transport in Nigeria - A case study of the petroleum downstream sector. Technol Forecast Soc Change. 131: 240252.

Tsakalidis A, Gkoumas K, Pekár F. 2020. Digital Transformation Supporting Transport Decarbonisation: Technological Developments in EU-Funded Research and Innovation. Sustainability. 12(3762): 1-13.

Wang Y, Potter A, Naim M, Beevor, D. 2011. A case study exploring drivers and implications of collaborative electronic logistics marketplaces. Ind Mark Manag. 40(4): 612-623.

Wang Y, Rodrigues VS, Evans L. 2015. The use of ICT in road freight transport for CO2 reduction - an exploratory study of UK's grocery retail industry. Int J Logist Manag. 26: 2-29. 